\title{
Sistem Pendukung Keputusan Kelayakan Penerimaan Bantuan Pinjaman Modal Usaha Kecil Menengah Dengan Metode Smart
}

\author{
Lutfi Singgih Pangestu ${ }^{1)}$, Yusriel Ardian $\left.{ }^{*}, 2\right)$, Wiwin Kuswinardi*,3) \\ ${ }^{1,2,3)}$ Program Studi Sistem Informasi, Universitas Kanjuruhan Malang, Indonesia \\ Email: ${ }^{1}$ lutfi.s.pangestu@ gmail.com, ${ }^{2}$ yusriel@ unikama.ac.id, ${ }^{3)}$ wiwinkuswinardi@unikama.ac.id
}

\begin{abstract}
Admission eligibility decision support systems help small and medium enterprises loan capital was built for the village BUMDes Slorok in determining who is eligible to receive assistance capital loans. In the process for the selection of beneficiaries of loans has a lot of requirements or criteria which are ID cards, Letter of approval husband / wife, status, number of families, home ownership, income, dependents of school children, old business, assets owned. In this study the feasibility of beneficiary selection process will be conducted by the method Simple Multi Attribute Rating Technique (SMART) Is a multi criteria decision making methods. The research model development using the Waterfall model. The results can be concluded from this study, the value obtained by each candidate receiving debt relief will dinputkan to this decision support system and be counted. Then displays the calculation results based on the rank ordering of where the highest score will be on top.
\end{abstract}

Keywords - decision support system; SMART; capital loan

\begin{abstract}
Abstrak. Sistem pendukung keputusan kelayakan penerimaan bantuan pinjaman modal usaha kecil menengah ini dibangun untuk Bumdes Desa Slorok dalam menentukan siapa yang layak menerima bantuan pinjaman modal. Pada proses kelayakan calon penerima bantuan pinjaman memiliki banyak persyaratan atau kriteria diantaranya adalah KTP, Surat persetujuan suami/istri, Status, Jumlah keluarga, Kepemilikan rumah, Pendapatan, Tanggungan anak sekolah, Lama usaha, Aset yang dimiliki. Pada penelitian ini proses kelayakan calon penerima bantuan akan dilakukan dengan metode Simple Multi Attribute Rating Technique (SMART) merupakan salah satu metode sistem pendukung keputusan multi kriteria. Model penelitian pengembangan menggunakan model Waterfall. Hasil yang dapat disimpulkan dari penelitian ini, nilai yang diperoleh oleh masing-masing calon penerima bantuan pinjaman akan dinputkan ke dalam sistem pendukung keputusan dan akan dihitung secara otomatis. Kemudian hasil yang diperoleh akan ditampilkan berdasarkan urutan ranking dimana pemohon yang nilai dengan skor tinggi akan berada di atas.
\end{abstract}

Kata Kunci - sistem pendukung keputusan; SMART; pinjaman modal

\section{Pendahuluan}

\section{A. Latar Belakang}

Salah satu indikator kemajuan pembangunan suatu daerah adalah dimana pemerintah daerah dan masyarakatnya mampu mengelola bersama sumber daya yang ada dan membentuk kerjasama antara pemerintah daerah dengan masyarakat untuk menciptakan suatu lapangan kerja baru untuk meningkatkan pertumbuhan ekonomi dalam daerah tersebut. Pihak pemerintah bertanggung jawab dalam hal peningkatan ekonomi dan sumber daya masusia.

Progam bantuan modal usaha bergulir adalah salah satu rencana progam dari Badan Usaha Milik Desa (Bumdes) Desa Slorok yang dibuat untuk mengatasi maslah ekonomi dalam lingkup Desa Slorok. Progam bantuan modal usaha bergulir ini berupa dana kredit dibuat untuk meningkatkan kualitas kehidupan masyarakat miskin dengan mengucurkan bantuan kredit modal untuk membantu masyarakat desa dalam mengembangkan usaha, yang menjadi sasaran dari progam ini adalah usaha kecil menengah (UKM).

Proses verifikasi kelayakan calon penerima dana pihak BUMDes masih melakukan proses seleksi secara manual dan tidak dilakukan perhitungan, tentunya hal ini dapat menimbulkan permasalahan dalam proses verivikasi kelayakan dan adanya unsur subjektif berdasarkan kedekatan personal dalam menentukan penerima dana. Hal ini akan mngakibatkan terjadinya ketidak akuratan dalam penyaluran dana.

Oleh karena itu peneliti ingin membuat "sistem pendukung keputusan kelayakan penerimaan bantuan pinjaman modal usaha kecil menengah dengan metode SMART" untuk membantu pihak Bumdes dalam menetukan kelayakan calon penerima bantuan tepat sasaran. Metode SMART (Simple Multi Attribut Rating Technique) adalah teknik pendukung keputusan multi kriteria, bahwa setiap alternatif yang digunakan terdiri dari sejumlah kriteria dengan nilainilai dan setiap kriteria itu sendiri memiliki bobot untuk menggambarkan seberapa penting kriteria tersebut 
dibandingkan dengan kriteria-kriteria lainnya.

\section{B. Batasan Masalah} berikut:

Batasan dari penelitian pengembangan sistem pendukung keputusan dengan metode SMART ini adalah sebagai

1.Penentuan kelayakan berdasarkan kriteria KTP, surat persetujuan suami/istri, status, jumlah keluarga, kepemilkan rumah, pendapatan, tanggungan anak sekolah, lama usaha, dan asset yang dimiliki.

2.Sistem dikembangkan menggunakan Bahasa pemograman PHP dan media penyimpanan data menggunakan database MySQL.

3.Menggunkan metode Metode SMART (Simple Multi Attribut Rating Technique).

\section{Tujuan Penelitian}

Berdasarkan uraian diatas, tujuan dari penelitian ini adalah sebagai berikut:

Penerapan sistem pendukung keputusan kelayakan penerimaan bantuan pinjaman modal usaha kecil menengah dengan metode SMART dapat memudahkan pihak BUMDes Desa Slorok dalam menentukan kelayakan penerima bantuan modal usaha.

\section{Referensi Artikel Penelitian}

Adapun jurnal rujukan sebagaai refrensi yang telah berhasil yaitu "sistem pendukung keputusan seleksi penerimaan calon asisten praktikum menggunakan metode SMART" yang ditulis oleh Yaya Sulviyana pada tahun 2017 dengan kesimulan sebagai berikut: 1) Kriteria, Sub Kriteria dan variable sangat berpengaruh dalam hasil perhitungan yang diperoleh, 2) Metode Simple Multi Attribute Rating Technique (SMART) telah berhasil diterapkan [6].

Jurnal rujukan "implementasi metode smart pada sistem pendukung keputusan pemilihan kegiatan ekstrakurikuler untuk siswa sma" yang ditulis oleh Tisa Magrisa pada tahun 2018 dengan kesimpulan sebagai berikut: 1) Sistem telah dapat membantu siswa dalam memberikan keputusan pemilihan kegiatan ekstrakurikuler dengan tingkat akurasi pengujian sebesar 84,39\%. 2). Informasi yang ditanpilkan pada daftar ekskul sudah bermanfaat terbukti dengan tingkat akurasi pengujian sebesar 80,976\%. 3) Setiap fungsionalitas yang ada pada sistem telah bekerja sesuai dengan yang diharapkan. 4) Berdasarkan respon yang diberikan oleh responden, maka pengguna menyatakan sangat setuju bahwa sistem ini telah telah dapat diterima dengan tingkat akurasi sebesar 83,089 [4].

Jurnal rujukan "implementasi sistem pendukung keputusan dengan metode smart untuk merangking kemiskinan dalam proses penentuan penerima bantuan pkh" yang ditulis oleh Faizal pada tahun 2017 dengan kesimpulan sebagai berikut: 1) Metode SMART berhasil menyelesaikan masalah seleksi penerima bantuan PKH dengan hasil 20 orang yang berhasil masuk dalam desil 1 dan 5 orang yang menjadi calon penerima bantuan PKH. 2) Kriteria mempengaruhi perhitungan SMART, semakin banyak kriteria yang digunakan maka semakin baik hasil yang didapat [3].

\section{METODE}

\section{A. Model Penelitian Pengembangan}

Model Pengembangan Perangkat Lunak atau yang bisaa disebut System Development Life Cycle (SDLC), adalah "Proses mengembangkan atau mengubah suatu sistem perangkat lunak dengan menggunakan model-model dan metodologi yang digunakan orang untuk mengembangkan sistem-sitem perangkat lunak sebelumnya" [1]. Penelitian ini menggunakan model penelitian pengembangan pada sistem ini mengacu pada model pengambangan Waterfall. Terdapat 5 tahapan dalam model pengembangan waterfall seperti pada gambar berikut ini:

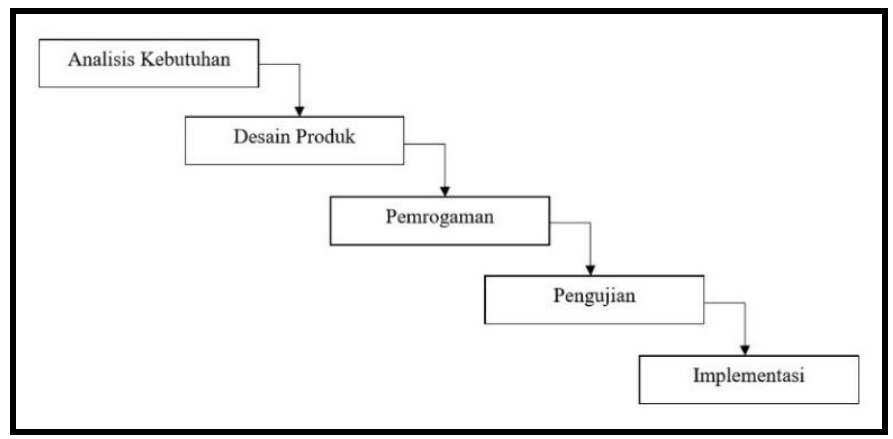

Gambar 1. Model Pengambangan Waterfall

\section{B. Instrumen Pengumpulan Data}

Instrumen pengumpulan data yang digunakan dalam penelitian ini adalah sebagai berikut :

1.Observasi, Untuk mengetahui situasi, kondisi dan permasalahan yang ada pada BUMDes Desa Slorok. 
2.Wawancara, Untuk mendapatkan infromasi mengenai data proses kelayakan penerimaan bantuan modal usaha berdasarkan ketentuan kriteria yang sudah ditentukan pada BUMDes Desa Slorok.

\section{Teknik Analisis Data}

Teknik analisis data yang digunakan dalam penelitian ini menggunakan metode SMART [3]. Adapun proses analisis data menggunakan metode SMART sebagai berikut:

1.Menentukan banyaknya kriteria digunakan.

2.Menentukan bobot kriteria pada masing-masing kriteria dengan menggunakan jarak nilai 1\%-100\% untuk masing-masing setiap kriteria dengan prioritas terpenting mendapat nilai terbesar.

3.Menghitung nilai normalisasi untuk setiap kriteria dengan pembandingan nilai bobot masing-masing kriteria dengan jumlah bobot masing-masing kriteria. Dengan rumus:

Normalisasi $=\frac{W_{j}}{\sum W_{j}}$

Keterangan:

$\mathrm{Wj} \quad=$ Bobot suatu kriteria

$\Sigma W_{j}=$ Total jumlah bobot

4.Memberikan nilai parameter pada setiap sub-kriteria untuk setiap alternatif.

5.Menentukan nilai utiliti dengan mengonversikan nilai parameter pada sub-kriteria menjadi nilai data baku.

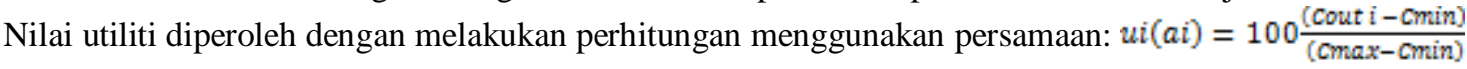

6.Menentukan nilai akhir dari masing-masing kriteria dengan mengalihkan nilai yang didapat dari normalisasi nilai kriteria data baku dengan nilai normalisasi bobot kriteria. Kemudian jumlahkan nilai dari perkalian tersebut.

\section{Hasil dan Pembahasan}

\section{A. Proses Perhitungan Metode SMART}

Pemeliti menggunakan metode SMART (Simple Multi Attribut Rating Technique). Urutan dalam penggunaan metode SMART adalah sebagai berikut: urutan dalam penggunaan metode SMART adalah sebagi berikut:

1. Menentukan banyaknya kriteria digunakan.

Kriteria yang akan digunakan ada 9 kriteria yaitu KTP, Surat persetujuan suami/istri, Status, Jumlah keluarga, Kepemilikan rumah, Pendapatan, Tanggungan anak sekolah, Lama usaha, Aset yang dimiliki.

2. Menentukan bobot kriteria pada masing-masing kriteria dengan menggunakan jarak nilai $1 \%-100 \%$ untuk masing-masing setiap kriteria dengan prioritas terpenting mendapat nilai terbesar.

Tabel 1. Bobot Kriteria

\begin{tabular}{ccc}
\hline No & Kriteria & Bobot \\
\hline $\mathbf{1}$ & KTP & $5 \%$ \\
\hline $\mathbf{2}$ & Surat Persetujuan Suami/Istri & $5 \%$ \\
\hline $\mathbf{3}$ & Status & $5 \%$ \\
\hline $\mathbf{4}$ & Jumlah Keluarga & $15 \%$ \\
\hline $\mathbf{5}$ & Kepemilikan Rumah & $5 \%$ \\
\hline $\mathbf{6}$ & Pendaapatan & $25 \%$ \\
\hline $\mathbf{7}$ & Tanggungan Anak Sekolah & $15 \%$ \\
\hline $\mathbf{8}$ & Lama Usaha & $15 \%$ \\
\hline $\mathbf{9}$ & Aset yang Dimiliki & $10 \%$ \\
\hline
\end{tabular}

3. Menghitung nilai normalisasi untuk setiap kriteria dengan pembandingan nilai bobot masing-masing kriteria dengan jumlah bobot masing-masing kriteria. Menggunakan rumus :

Normalisasi $=\frac{W j}{\sum W_{j}}$

Keterangan:

$\mathrm{Wj} \quad=$ Bobot suatu kriteria

$\Sigma W_{j}=$ Total jumlah bobot

a) $\mathrm{KTP}=5 / 100=0,05$

b) Surat persetujuan suami $/ \mathrm{i}=5 / 100=$ 0,05

c) Status $=5 / 100=0,05$

d) Jumlah keluarga $=15 / 100=0,15$

e) Kepemilikan rumah $=5 / 100=0,05$ f) Pendapatan $=25 / 100=0,25$

g) Tanggungan anak sekolah $=15 / 100$ $=0,15$

h) Lama usaha $=15 / 100=0,15$

i) Aset yang dimiliki $=10 / 100=0,10$ 
4. Memberikan nilai parameter pada setiap sub-kriteria untuk setiap alternatif.

Tabel 2. Nilai Parameter

\begin{tabular}{|c|c|c|c|}
\hline No & Kriteria & Sub Kriteria & $\begin{array}{c}\text { Nilai } \\
\text { Parameter }\end{array}$ \\
\hline \multirow[t]{2}{*}{1} & \multirow[t]{2}{*}{ KTP } & Ada & 7 \\
\hline & & Tidak ada & 1 \\
\hline \multirow[t]{3}{*}{2} & \multirow{3}{*}{$\begin{array}{l}\text { Surat Persetujuan } \\
\text { Suami/istri }\end{array}$} & Ada & 7 \\
\hline & & Duda/Janda & 7 \\
\hline & & Tidak ada & 1 \\
\hline \multirow[t]{3}{*}{3} & \multirow[t]{3}{*}{ Status } & Duda/Janda & 6 \\
\hline & & Menikah & 7 \\
\hline & & Belum Menikah & 5 \\
\hline \multirow[t]{4}{*}{4} & \multirow[t]{4}{*}{ Jumlah Keluarga } & 4 keatas & 7 \\
\hline & & 3 & 6 \\
\hline & & 2 & 4 \\
\hline & & 1 & 3 \\
\hline \multirow[t]{2}{*}{5} & \multirow[t]{2}{*}{ Kepemilikan Rumah } & Milik Sendiri & 6 \\
\hline & & Sewa & 7 \\
\hline \multirow[t]{7}{*}{6} & \multirow[t]{7}{*}{ Pendapatan } & Diatas 5 juta & 1 \\
\hline & & Diantara 3,5 juta -5 juta & 2 \\
\hline & & Diantara 2,5 juta $-3,5$ juta & 3 \\
\hline & & Diantara 1,5 juta $-2,5$ juta & 4 \\
\hline & & Diantara 1 juta $-1,5$ juta & 5 \\
\hline & & Diantara 500 ribu - 1 juta & 6 \\
\hline & & Dibawah 500 ribu & 7 \\
\hline \multirow[t]{4}{*}{7} & \multirow{4}{*}{$\begin{array}{l}\text { Tanggungan Anak } \\
\text { Sekolah }\end{array}$} & 3 keatas & 7 \\
\hline & & 2 & 5 \\
\hline & & 1 & 4 \\
\hline & & Tidak ada & 1 \\
\hline \multirow[t]{3}{*}{8} & \multirow[t]{3}{*}{ Lama Usaha } & Kurang dari 1 tahun & 7 \\
\hline & & Antara 1 tahun sampai 3 tahun & 5 \\
\hline & & Lebih dari 3 tahun & 3 \\
\hline \multirow[t]{6}{*}{9} & \multirow[t]{6}{*}{ Aset yang Dimiliki } & Tidak ada & 7 \\
\hline & & Kendaraan roda 2 & 6 \\
\hline & & Rumah & 6 \\
\hline & & Rumah, Kendaraan roda 2 & 5 \\
\hline & & Rumah, Kendaraan roda 2, Tanah & 2 \\
\hline & & Rumah, Kendaraan roda 2, Tanah, dll & 1 \\
\hline
\end{tabular}

5. Menentukan nilai utiliti dengan mengonversikan nilai parameter pada sub-kriteria menjadi nilai data baku. Nilai utiliti diperoleh dengan melakukan perhitungan menggunakan persamaan:

$u i(a i)=100 \frac{(\text { Cout } i-C \min )}{(\text { Cmax }- \text { Cmin) }}$

Dimana nilai utiliti kriteria ke-1 untuk kriteria ke-1, Cmax adalah nilai kriteria maksimal, Cmin adalah nilai kriteria minimal dan Cout $\mathrm{i}$ adalah nilai kriteria. $\mathrm{Cmax}=7, \mathrm{Cmin}=1$

$$
\begin{aligned}
u 1(a 1) & =\frac{7-1}{7-1}=1 \\
u 2(a 2) & =\frac{6-1}{7-1}=0,83 \\
u 3(a 3) & =\frac{\frac{7}{7-1}}{7-1}=0,66 \\
u 4(a 4)=\frac{4-1}{7-1}= & 0,5
\end{aligned}
$$

$$
\begin{aligned}
& u 5(a 5)=\frac{3-1}{7-1}=0,33 \\
& u 6(a 6)=\frac{2-1}{7-1}=0,16 \\
& u 7(a 7)=\frac{1-1}{7-1}=0
\end{aligned}
$$

6. Menentukan nilai akhir dari masing-masing kriteria dengan mengalihkan nilai yang didapat dari normalisasi nilai kriteria data baku dengan nilai normalisasi bobot kriteria. Kemudian jumlahkan nilai dari perkalian tersebut. 
calon 1, KTP ada, Surat persetujuan suami/istri ada, Status menikah, Jumlah Keluarga 4, Kepemilikan rumah milik sendiri, Pendapatan diantara 500 ribu sampai 1 juta, Tanggungan anak sekolah 2, Lama usaha kurang dari 1 tahun, Aset yang dimiliki Rumah dan kendaraan roda 2. Maka nilai akhir adalah sebagai berikut:

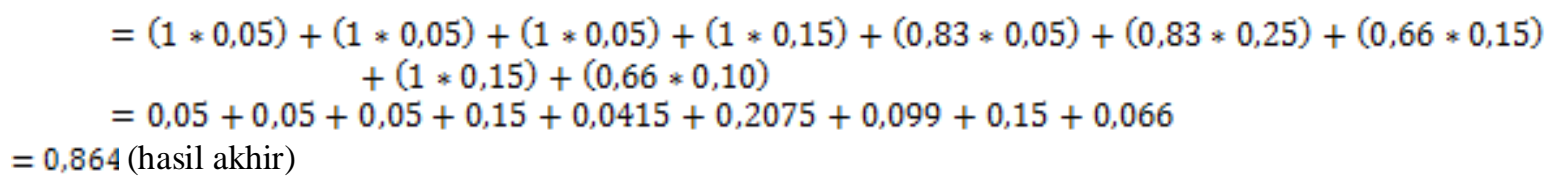

\section{B. Desain Awal Produk}

1. Analisis kebutuhan

Pada penelitian ini analisis kebutuhan digunakan untuk memahami kebutuhan dari sebuah sistem. Analisis kebutuhan yang dilakukan meliputi observasi dan wawancara.

\section{Desain Produk}

Pada tahap desain produk, peneliti melanjutkan dari tahapan analisis kebutuhan. Tahapan desain produk dalam penelitian ini dilakukan dengan 2 tahapan yaitu:

1.Merancang desain sistem pendukung keputusan kelayakan penerimaan bantuan modal usaha kecil menengah dengan metode SMART menggunakan UML (Unified Modelling Language) yang akan dibagi menjadi Use case, Sub use case, Activity diagram, Sequence diagram dan Class diagram sebagai perancangan sistem [5].

2.Desain tampilan, pada sub-tahapan ini adalah peneliti akan melakukan desain tampilan (user interface) dari setiap halaman pengguna.

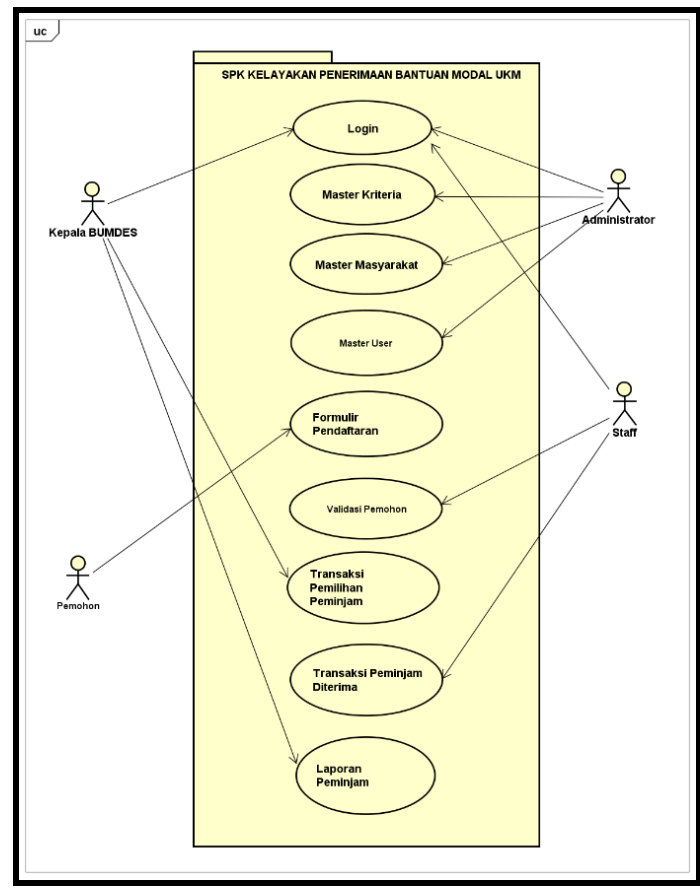

Gambar 2. Use Case Diagram Utama

Penjelasan use case diagram utama adalah sebagai berikut:

1.Login digunakan untuk memvalidasi pengguna agar bisa menggunakan fitur yang sesuai dengan hak akses pengguna.

2.Master user digunakan oleh administrator untuk memanipulasi data user.

3.Master kriteria digunakan oleh administrator untuk memanipulasi data kriteria yang digunakan.

4.Master masyarakat digunakan oleh administrator untuk melihat, menambah, mengubah dan menghapus data masyarakat.

5.Formulir Pemohon digunakan oleh pemohon untuk melakukan mengisi form pendaftaran.

6.Validasi Pemohon digunakan oleh staff untuk melakukan proses validasi pemohon yang telah mengisi formulir

7.Transaksi pemilihan peminjam digunakan oleh Kepala Bumdes untuk memilih calon penerima bantuan pinjaman.

8.Transaksi peminjam diterima digunakan oleh staff untuk melakukan proses pencairan dana bantuan untuk peminjam yang telah terpilih. 
9.Laporan pinjaman digunakan oleh Kepala Bumdes untuk melihat laporan peminjam yang telah diterima.

\section{Pemograman}

Pada tahap proses pemrograman, peneliti melakukan pembuatan kode program sesuai hasil tahapan desain produk. Tahap ini mengimplementasikan hasil rancangan ke dalam baris kode dan tampilan sistem yang berjalan sesuai dengan fungsinya.

\section{Pengujian}

Pengujian produk dilakukan setelah tahap pemrograman selesai, pengujian produk dilakukan dengan blackbox testing dan user acceptance test. Pengujian ini ditentukan untuk membuktikan bahwa semua obyek dalam system telah melakukan fungsi sesuai yang diharapkan.

\section{Implementasi}

Pada tahap implentasi dilakukan pendampingan secara langsung cara penggunaan sistem kepada pengguna yaitu pihak Bumdes.

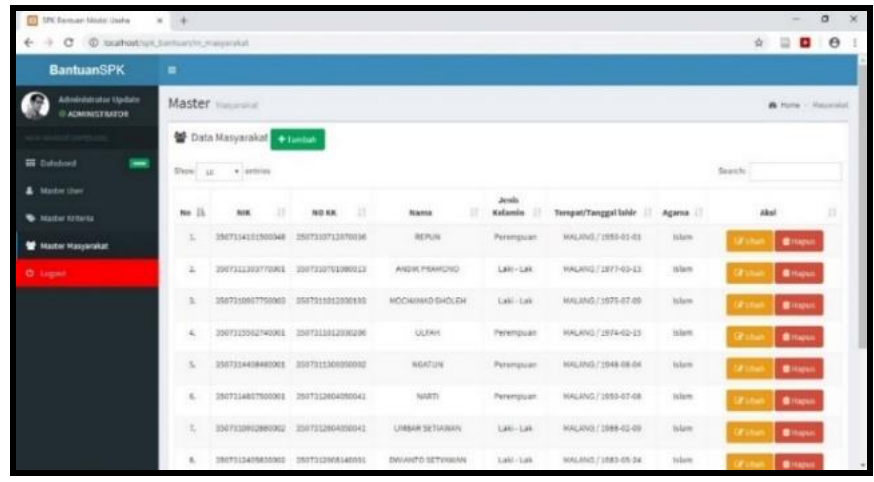

Gambar 3. Master Masyarakat

Pada fungsi master masyarakat, administrator dapat melihat dan melakukan manipulasi data kriteria dengan menambah, menghapus, dan mengubah.



\section{Gambar 4. Master Kriteria}

Pada fungsi master kriteria, administrator dapat melihat dan melakukan manipulasi data kriteria dengan menambah, menghapus, dan mengubah.

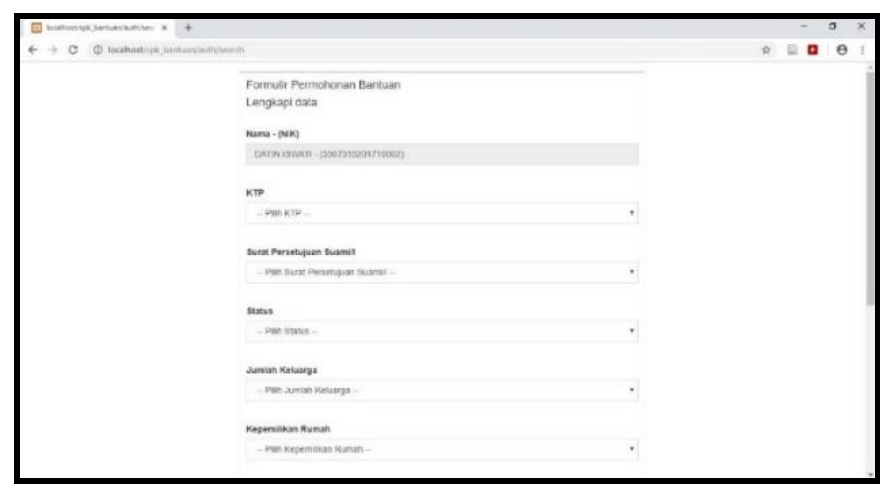

Gambar 5. Formulir Permohonan

Pada fungsi formulir permohonan, pemohon dapat melakukan pendaftaran dengan mengisi form yang 
telah disediakan sesuai dengan data kriteria pemohon.

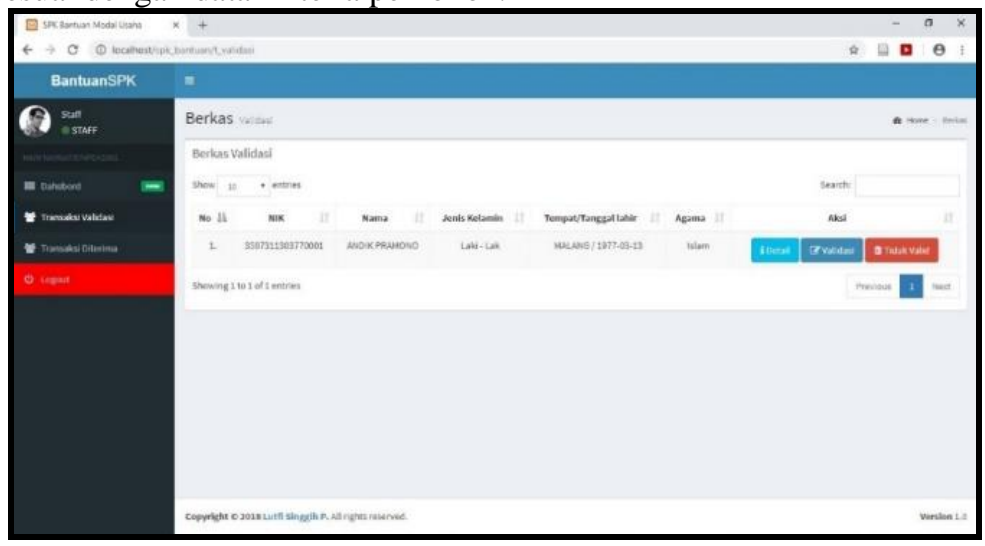

Gambar 6. Validasi Pemohon

Pada fungsi validasi pemohon, staff dapat melakukan validasi data pemohon yang telah mendaftar dengan cara melihat data pemohon.

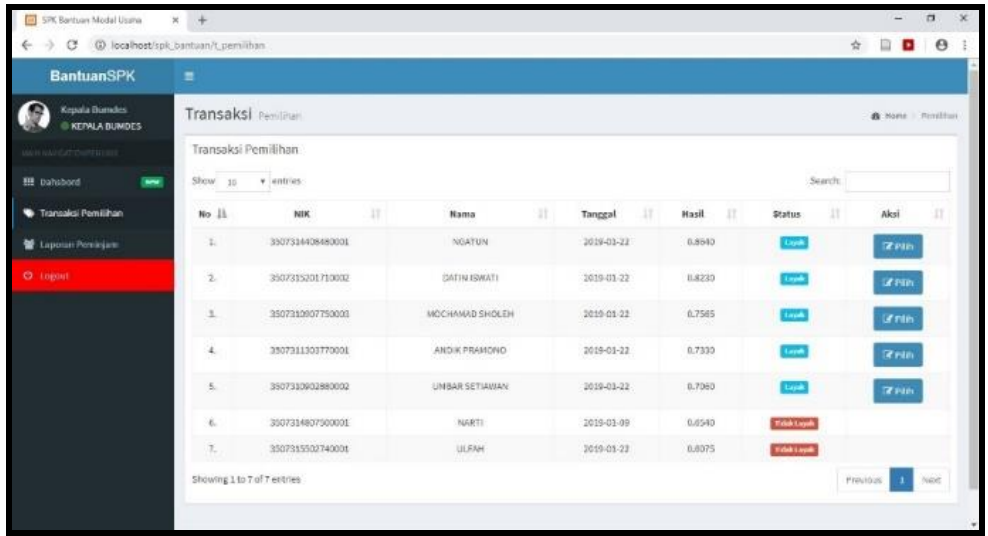

Gambar 7. Transaksi Pemilihan

Pada fungsi transaksi pemilihan, Kepala Bumdes dapat melakukan pemilihan penerima bantuan pinjaman modal dengan nilai skor tertinggi.

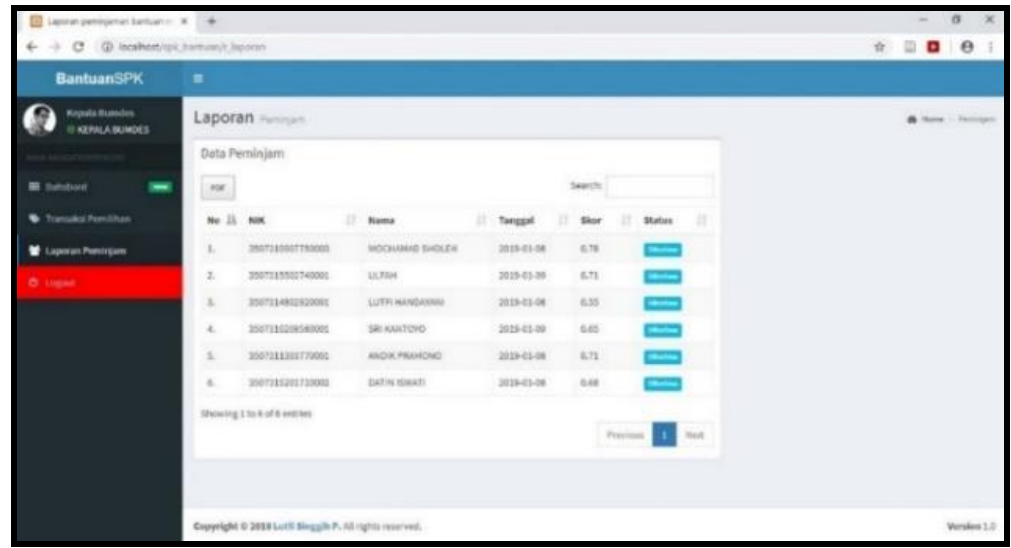

Gambar 8. Laporan Peminjaman

Pada fungsi laporan peminjaman, Kepala Bumdes dapat melakukan proses export/cetak laporan.

\section{KESIMPULAN}

Berdasarkan hasil penelitian dan uji coba sistem yang dilakukan pada penentuan kelayakan penerimaan bantuan pinjaman modal usaha kecil menengah dengan menggunakan metode SMART (Simple Multi Attribut Rating Technique), dapat ditarik kesimpulan bahwa sistem mampu menentukan kelayakan pada calon penerima bantuan pinjaman berdasarkan kriteria yang telah ditentukan dan mampu merangkingkan nilai tertinggi pada masing-masing calon penerima bantuan pinjaman. Serta memudahkan pihak Bumdes untuk melakukan proses pemilihan dengan tepat 
dan layak.

\section{UCAPAN TERIMA KASIH}

Ucapan terimakasih sebesar-besarnya saya ucapkan kepada teman-teman "coding bahagia" yang telah membantu saya dan menyemangati saya. Kepada kedua orangtua saya yang selalu senantiasa memberikan dukungan baik moril maupun materil serta do'a yang tiada henti-hentinya kepada saya. Serta kepada Bapak M. Asni Fitrian selaku Kepala Bumdes dan Mas M. As'ari Fuddin selaku staff Bumdes Desa Slorok yang telah mengijinkan dan membantu saya untuk melakukan kegiatan penlitian di Bumdes Desa Slorok. Serta banyak ucapan terimakasih kepada bapak Yusriel dan bapak Wiwin selaku dosen pembimbing yang telah membantu dan membimbing dalam proses penulisan dan penelitian ini. Tidak lupa kepada Rektor Universitas Kanjuruhan Malang Bapak Dr. Pieter Sahertain, M.Si., dan Dekan Fakultas Sains dan Teknologi Dr. I Ketut Suastika, M.Si., serta paraa pembantu dan staff Fakultas Sains dan Teknologi (FST) serta Kaprodi Sistem Infromasi Yoyok Seby Dwanoko, S.Kom, M.Kom., beserta seluruh staffnya saya mengucapkan banyak-banyak terimakasih.

\section{REFERENSI}

[1] A.S Rosa \& M.Shalahuddin. 2014. Rekayasa Perangkat Lunak Struktur dan Berorientasi Objek. Bandung : Informatika.

[2] Dicky Nofriansyah \& Sarjon Defit. 2017.Multi Criteria Decision Making (MCDM) pada sistem pendukung keputusan. Yogyakarta: Budi Utama.

[3] Faizal \& Fatma Agus Setyaningsih \& Muhammad Diponegoro. 2017. Implementasi Sistem Pendukung Keputusan dengan Metode SMART untuk Merangking Kemiskinan dalam Proses Penentuan Penerima Bantuan PKH. Pontianak: Universitas Tanjungpura

[4] Magrisa, Tisa \& Kartika Diah Kusuma Wardhani \& Maksum Ro’is Adin Saf. 2018. Implementasi Metode SMART pada Sistem Pendukung Keputusan Pemilihan Kegiatan Ekstrakurikuler Untuk Siswa SMA. Samarinda: Universitas Mulawarman

[5] Muslihudin, Muhammad \& Oktafianto. 2016. Analisis dan Perancangan Sistem Informasi Menggunakan Model Terstruktur dan UML. Yogyakarta: Andi

[6] Sulviyana, Yaya \& Andi Tejawati \& Ummul Hairah. 2017. Sistem Pendukung Keputusan Selesksi Penerimaan Calon Asiten Praktikum Menggunakan Metode SMART. Samarinda: Universitas Mulawarman 